\title{
H2BC19P Gene
}

National Cancer Institute

\section{Source}

National Cancer Institute. H2BC19P Gene. NCI Thesaurus. Code C162792.

This gene may be involved in the structure of histone complexes. 